\title{
Antibodies to colonic epithelial cells from the serum and colonic mucosal washings in ulcerative colitis
}

\author{
U Y Khoo, I Bjarnason, A Donaghy, Roger Williams, A Macpherson
}

\begin{abstract}
It has been suggested that antibodies to a colonocyte protein of $40 \mathrm{kD}$ (an intestinal isoform of tropomyosin) are specifically found in the serum and mucosa of patients with ulcerative colitis, which has important pathogenic implications. This study isolated and purified tropomyosin from the colonic mucosa, but no specific binding to this protein has been detected in serum samples or immunoglobulins isolated from mucosal washings of 20 ulcerative colitis (UC) patients by enzyme linked immunosorbent assay (ELISA) compared with 21 controls or 17 Crohn's disease (CD) patients. Samples from a further 12 patients with UC and primary sclerosing cholangitis (it is proposed that cross reactivity against the intestinal tropomyosin isoform accounts for the extraintestinal disease) also did not show binding to tropomyosin, whereas monoclonal antitropomyosin antisera bound both ELISAs and western blots. This study also examined the proteins in the normal colonic biopsy specimens on western blots that are bound by both serum samples and mucosal immunoglobulin preparations from these patients groups; there was no specific IgG or IgA binding to patients with UC or UC/primary sclerosing cholangitis, whereas binding to mitochondrial proteins of 70000 and 45000 was seen in samples from 12 primary biliary cirrhosis positive controls. This work does not support the hypothesis that autoimmune activity against the intestinal isoform or tropomyosin is important in the pathogenesis of ulcerative colitis.

(Gut 1995; 37: 63-70)
\end{abstract}

Keywords: ulcerative colitis, colonic epithelial cells, colonic mucosal washings.

Following the first description of antimucin antibodies by Broberger and Perlman (1959) in patients with ulcerative colitis (UC), the possibility that autoimmune damage of the colonic epithelium is important in the pathogenesis of UC has attracted considerable attention. ${ }^{12}$ While there is certainly a weak epidemiological association between UC (but not Crohn's disease) and other well characterised autoimmune conditions, ${ }^{3}$ it remains unclear whether any of the antigens that have been so far described from in vitro studies are actually important in the pathogenesis of the condition.

The proposed colonic autoantibodies in UC fall into two groups. The first is the 'classic' antigoblet (antimucin) antibody, present in patient serum and capable of binding to goblet cells on tissue sections in vitro, ${ }^{4}$ which is directed against mucin proteins of 130,160 , and $>200 \mathrm{kD} .{ }^{56}$ Antimucin antibodies are also found, however, in the healthy relatives of inflammatory bowel disease patients, ${ }^{6}$ and in patients with non-inflammatory bowel disease intestinal inflammation and irritable bowel syndrome. ${ }^{7}$ Furthermore, as these antibodies do not correlate with antibody dependent cytotoxicity on colonocytes, 48 their pathogenic importance is in some doubt.

Secondly, Das and coworkers have published a series of papers in which they have characterised a $40 \mathrm{kD}$ epithelial cell antigen. ${ }^{9-14}$ This was originally isolated by showing that colon bound IgG in UC patients (but not from Crohn's disease or controls) recognised a $40 \mathrm{kD}$ protein in colon tissue extracts $^{13}$ with significant IgG titres to this protein in the serum samples of patients with UC. Using monoclonal antibodies they initially reported that the protein was detected on the basolateral surface of colonic epithelial cells and not in other tissues (including the ileum or liver)..$^{913}$ Later (using the same monoclonal antibody) the antigen has been shown at the apical surface of colonocytes and in the terminal ileum, biliary epithelium, skin, and fallopian tubes. ${ }^{14}$ Most recently, they have purified the $40 \mathrm{kD}$ protein and showed from peptide sequence analysis that it is an isoform of tropomyosin. ${ }^{12}$ Again they have suggested that there are antibody titres against tropomyosin in the serum samples of patients with UC, but not Crohn's disease or controls. ${ }^{12}$

Collectively, despite minor inconsistencies this adds up to a most intriguing story. Nevertheless there is very little independent evidence to support the hypotheses that (a) there are circulating and mucosal antibodies against the $40 \mathrm{kD}$ colonic tropomyosin isoform in patients with UC, or (b) these actually participate in the pathogenesis of the disease. Snook et al looked at autoantibodies against the colonic HT-29 cell line, but could not find cytotoxic anticolon antibodies in their extracts of IgG from surgical specimens undergoing colectomy for UC. ${ }^{4}$ The significance of these findings relied on the assumption that HT-29 cells are sufficiently differentiated to express the relevant epitopes. In a different approach 
Cantrell et al ${ }^{15}$ were unable to detect circulating autoantibodies in UC patients or controls to epithelial cell preparations in immunoblots, although this work was criticised on the grounds that the $40 \mathrm{kD}$ antigen may have been washed off the colonic cells during tissue preparation. ${ }^{14}$

In this paper we have looked for circulating and mucosal antiepithelial cell antibodies in UC, and examined the proposal that increased serum and mucosal titres of antitropomyosin antibodies (intestinal isoform) can be detected in patients with UC compared with Crohn's disease or controls.

\section{Methods}

\section{Patients}

Fifty eight patients were studied at the time of colonoscopy or flexible sigmoidoscopy to obtain endoscopic mucosal washings from which immunoglobulins were isolated. Parallel serum samples were also taken. The clinical indication for endoscopy was to investigate lower abdominal pain, changed bowel habit, or to define the extent or activity of inflammatory bowel disease.

In the case of 21 control patients ( $9 \mathrm{M}: 12 \mathrm{~F}$; 52 (19) years) (mean (SD)) no biochemical, haematological or microbiological abnormalities were found, radiology and histological parameters were normal, and a final diagnosis of irritable bowel syndrome was made in each case. Diagnoses of UC $(n=20 ; 12 \mathrm{M}: 8 \mathrm{~F} ; 42$ (17) years; disease duration 0-28 (9) years (range (mean)); four patients had coexistent primary sclerosing cholangitis) and Crohn's disease $(n=17 ; M: 10 \mathrm{~F} ; 40$ (12) years; disease duration $0-22$ (6) years) were made on standard criteria, ${ }^{16} 17$ with serial biopsy specimens providing histopathological assessment of disease activity. The distribution of disease for UC patients was 11 pancolitis, seven left sided, and two remission; for Crohn's disease, 13 ileocolonic, four colonic.

Serum samples were obtained from a further 32 patients (UC and primary sclerosing cholangitis $(n=12 ; 7 \mathrm{M}: 5 \mathrm{~F} ; 45$ (9) years; disease duration 2-18 (8) years; seven pancolitis, five left sided); primary biliary cirrhosis ( $n=12 ; 12 \mathrm{~F} ; 54$ (11) years)); control patients with intestinal inflammation $(n=8 ; 3 \mathrm{M}: 5 \mathrm{~F}$; 34 (13) years; five Salmonella colitis, one Shigellosis, one Campylobacter, one diverticulitis).

Informed consent was obtained from all patients, and the study was approved by the King's Healthcare Trust Ethical Committee.

\section{Isolation of immunoglobulins from intestinal mucosal washings}

Patients were prepared for colonoscopy by two oral doses of sodium picosulphate $(10 \mathrm{mg})$ taken 48 and 24 hours before the procedure and were sedated immediately before starting the examination by intravenous administration of $15 \mathrm{mg}$ diazepam and $75 \mathrm{mg}$ pethidine. Patients for flexible sigmoidoscopy were unprepared apart from a phosphate enema 90 minutes beforehand, and they were not sedated.

The colonic mucosa was washed under direct vision with $100 \mathrm{ml} 0.9 \%(\mathrm{w} / \mathrm{v})$ saline injected through the flush channel of an Olympus CF200HL videocolonoscope or flexible sigmoidoscope, with the patient positioned to ensure that the relevant colonic segment was in a dependent position. Great care was taken to aspirate any fluid encountered in the colon during insertion of the colonoscope, and washings were only performed during withdrawal of the instrument. The wash fluid was aspirated after two minutes through the suction channel, and immediately aliquoted into $10 \mathrm{ml} 1 \mathrm{mM}$ phenylmethylsulphonyfluoride to inhibit proteolysis. Immunoglobulins were either extracted immediately as described below, or the sample was frozen for up to two weeks at $-70^{\circ} \mathrm{C}$ before extraction.

\section{Precipitation of mucosal immunoglobulin from endoscopic washings}

To precipitate immunoglobulins, $50 \mathrm{ml}$ of $50 \%$ (w/v) polyethylene glycol (PEG) 4000 were slowly added to $100 \mathrm{ml}$ of mucosal washings while vortexing. This was centrifuged at $6000 \mathrm{~g}$ for 10 minutes at $4^{\circ} \mathrm{C}$. The supernatant was discarded, and the pellet containing immunoglobulin was resuspended in $2 \mathrm{ml}$ of $15 \%(w / v)$ PEG 4000; this was reprecipitated at $6000 \mathrm{~g}$ for 10 minutes at $4^{\circ} \mathrm{C}$, dried, and finally resuspended in $1 \mathrm{ml} 10 \mathrm{mM}$-TRISCl,

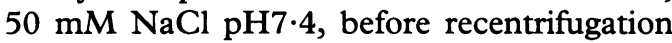
at $6000 \mathrm{~g}$ for 10 minutes at $4^{\circ} \mathrm{C}$ to remove undissolved material. The supernatant from this $(1 \mathrm{ml})$ was divided into 50 aliquots, and was found to be stable at $-20^{\circ} \mathrm{C}$ for up to four months, however, each aliquot was only thawed once immediately before use.

\section{ELISA quantification of immunoglobulins from mucosal washings}

To quantify mucosal immunoglobulins, a sandwich ELISA method was used. Microtitre plates (96 wells, Maxisorb, Nunc) were coated with $50 \mu$ l of monoclonal antihuman IgG and IgA (Sigma) at a dilution of 1:10000 and 1:1000 respectively by incubation at $4^{\circ} \mathrm{C}$ overnight. The plates were each washed three times with phosphate buffered saline (PBS) containing $0.05 \%(\mathrm{v} / \mathrm{v})$ TWEEN 20 before blocking with $10 \%(\mathrm{w} / \mathrm{v})$ bovine serum albumin in PBS for two hours at $25^{\circ} \mathrm{C}$ and washed a further three times in PBS-TWEEN. Samples of mucosal immunoglobulins were serially diluted in PBS-TWEEN, and $50 \mu \mathrm{l}$ of each was loaded in triplicate to the plates along with serial dilutions of a serum calibrant of known IgG and IgA content (Sheffield Protein Reference Unit). After incubation for two hours at $25^{\circ} \mathrm{C}$ the plates were again washed in PBS-TWEEN, and $50 \mu \mathrm{g}$ of $1 \mu \mathrm{g} / \mathrm{ml}$ biotinylated antihuman IgG (Vector Laboratories, BA3080) or biotinylated antihuman IgA (Vector Laboratories, BA3030) was added to each well and incubated for a further two hours at $25^{\circ} \mathrm{C}$. The plates were again washed three 
Molecular

weight

standards Colonic mucosal protein sample

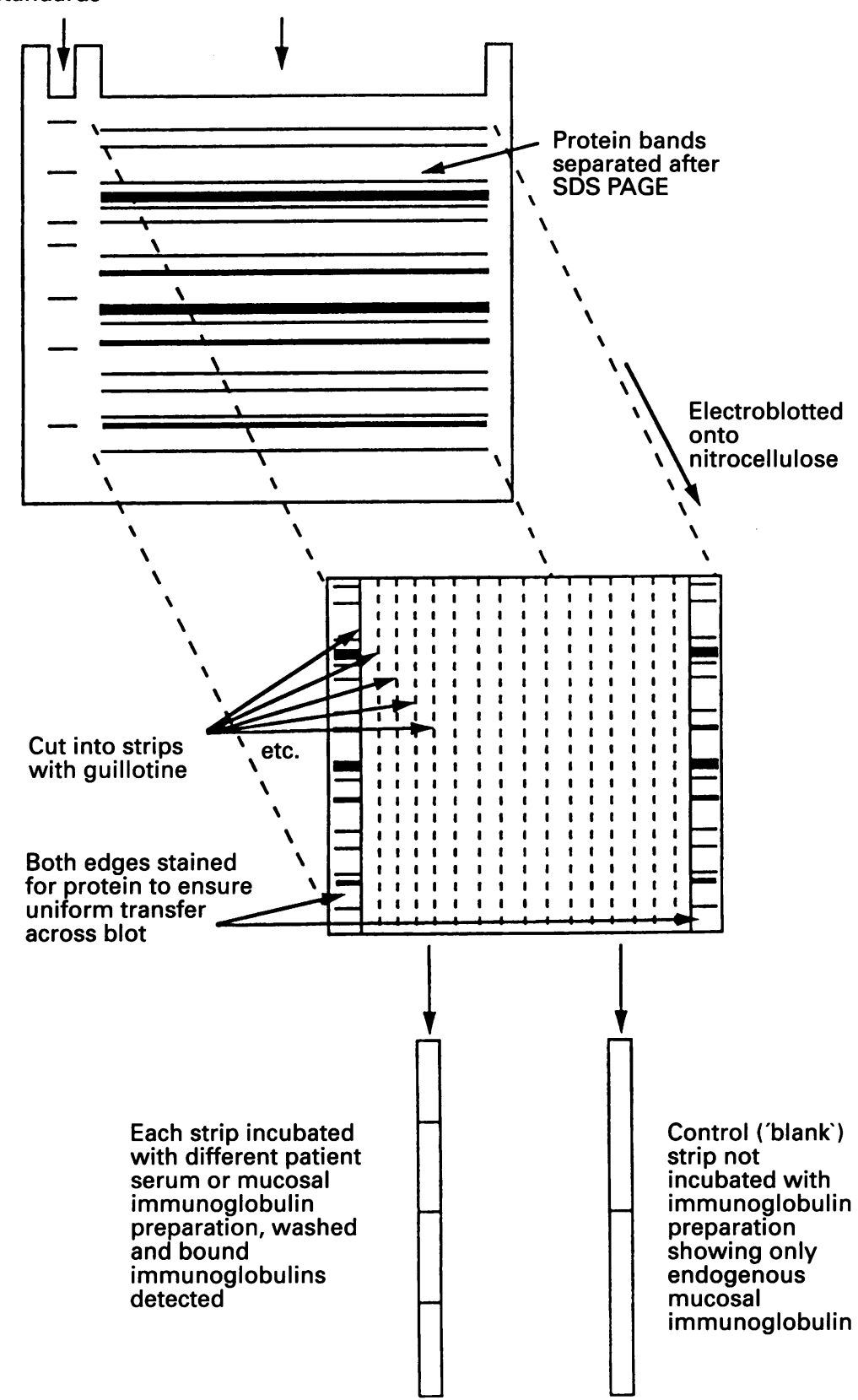

Figure 1: Method of assessing IgG or IgA binding to proteins on normal colonic biopsy specimens. Protein homogenates $(200 \mu \mathrm{g})$ were run in a single large well by $12.5 \%$ SDS polyacrylamide gel electrophoresis. Molecular weight markers were run in a separate lane at the side of the gel and stained separately. The separated colonic biopsy proteins were transferred to nitrocellulose, which was cut into strips, with each edge being stained for the colonic protein bands with India ink to ensure uniform transfer. Each intermediate strip was then incubated with either serum or mucosal immunoglobulin from an individual patient; after washing specifically bound antibodies were detected using biotin labelled antihuman IgG or IgA. Endogenous IgG or IgA within the biopsy specimen was shown using 'blank' strips where no serum or mucosal immunoglobulin had been added.

times with PBS-TWEEN, and each well was incubated with avidin-horseradish peroxidase complex and the bound peroxidase enzyme was detected using $100 \mu \mathrm{l} 4 \mathrm{mg} / \mathrm{ml} \quad o-$ phenylenediamine dihydrochloride in $50 \mathrm{mM}$ phosphate citrate buffer ( $\mathrm{pH} 5.0), 0.03 \%$ (w/v) sodium perborate. This reaction was stopped after five minutes by the addition of $100 \mu \mathrm{l}$ M sulphuric acid, and the absorbance in each well was read at $495 \mathrm{~nm}$ using a Titertek Multiscan $\mathrm{MCC} / 340$ plate reader. The sensitivity of the ELISAs was $\geqslant 10 \mathrm{ng} / \mathrm{ml}$ for both $\mathrm{IgG}$ and IgA.
Western blots

SDS poly $(12 \cdot 5 \%)$ acrylamide gels were run as described previously ${ }^{18}$ using a mini-V.8.10 electrophoresis system (BRL). Molecular weight markers (rabbit muscle myosin, 205 000; Escherichia coli $\beta$-galactosidase, 116000 ; rabbit muscle phosphorylase $B, 97$ 400; bovine serum albumin, 66000 ; bovine erythrocyte carbonic anhydrase, 29000 ; egg white lysozyme, 14300; Sigma) were run in a separate lane at the edge of the gel. Protein samples $(200 \mu \mathrm{g})$ from colonic mucosal biopsy specimens were prepared as described previously ${ }^{19}$ and were run in a single large well on each gel to achieve uniform separation of the proteins (Fig 1). After electrophoresis, the gels were either stained with Coomassie Blue $R$, or transferred to Hybond $\mathrm{C}$ (Amersham) using the electroblot stack assembly $(150 \mathrm{~V}, 1$ hour) with $25 \mathrm{mM}$-TRIS $\mathrm{HCl} ; 192 \mathrm{mM}$ glycine, $10 \%(\mathrm{v} / \mathrm{v})$ methanol ( $\mathrm{pH} 8 \cdot 3)$ transfer buffer. The blots were dried and a strip at each end was removed (Fig 1) and stained with India ink to ensure clean separation of the mucosal proteins and uniform transfer. Markers were also visualised in a separate narrow well on the edge of the gel by India ink staining. Between the end strips the blots of mucosal proteins were sectioned into $2 \mathrm{~mm}$ strips and processed.

Each strip of the mucosal protein blot was washed in PBS containing 0.05\%-TWEEN 20 , and blocked by incubation in $10 \%$ bovine serum albumin at room temperature for one hour. They were then washed again in PBSTWEEN and incubated with different samples of serum $(500 \mu \mathrm{l})$ or mucosal immunoglobulin $(300 \mu \mathrm{l})$ preparations at a dilution of 1 in 50 in separate test tubes for two hours. The strips were individually washed three times with $5 \mathrm{ml}$ of PBS-TWEEN in each tube and then incubated with biotinylated antihuman IgG (Vector Laboratories, BA3080) or antihuman IgA (Vector Laboratories, BA3030) at dilutions of $1: 1000$ and $1: 1500$ respectively. After washing three more times in $5 \mathrm{ml}$ PBS-TWEEN, bound immunoglobulin was detected on each strip by incubation with avidin-horseradish peroxidase complex for 30 minutes at $25^{\circ} \mathrm{C}$ (Vectastain Elite ABC, Vector Laboratories); unbound enzyme was washed off with PBS-TWEEN and the enzyme was detected using diaminobenzidine as a substrate.

Preparation of human colonic tropomyosin Tropomyosin was prepared by the method of Cummins and Perry ${ }^{20}$ from mucosal scrapings of human colon taken from four anterior resection specimens, at least $18 \mathrm{~cm}$ from the adenocarcinomas. The mucosal scrapings were homogenised in $15 \mathrm{ml} 1 \mathrm{M} \mathrm{KCl}$ using a Dounce homogeniser (Kontes Glass, Vineland, NJ), with 10 strokes of the loose fitting and 10 strokes of the tight fitting pestle. Undissolved material was removed by centrifugation (Sorvall RC2B centrifuge, GSA rotor, $6000 \mathrm{~g}$ ) and the supernatant was acidified to pH 4.6 and stirred at room temperature for one hour. The precipitate was subject to four 


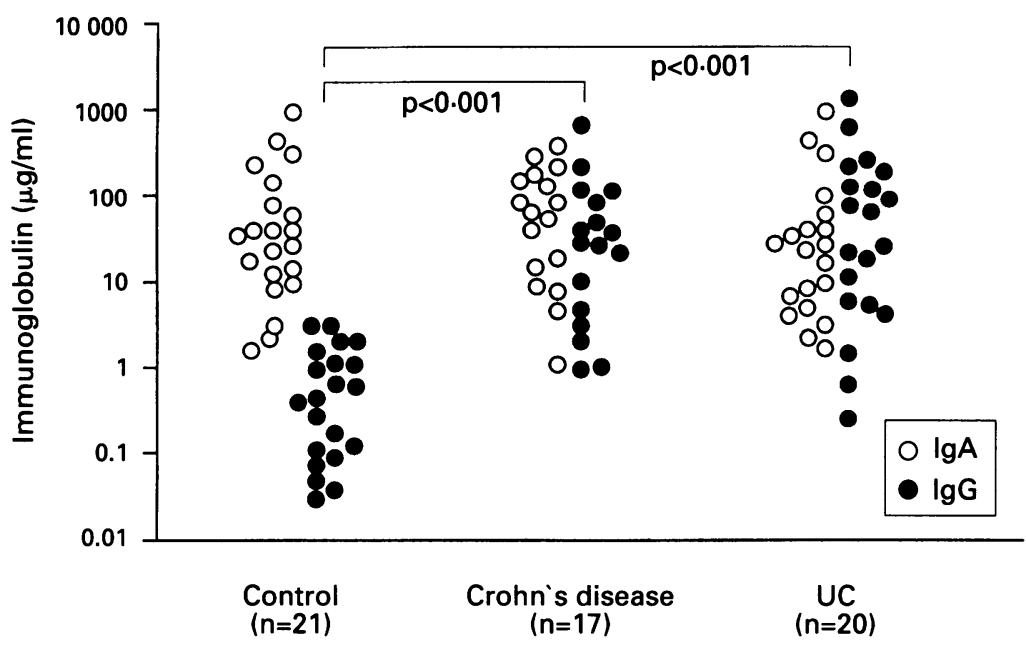

Figure 2: Immunoglobulins isolated from colonic washings in controls and patients with inflammatory bowel disease quantified by sandwich ELISA assay. Concentrations of IgG (solid circles) were significantly greater in patients with UC and Crohn's disease compared with controls ( $p<0.001$ in each case) whereas IgA concentrations (open circles) were not significantly different between the three groups.
TM311, Sigma). After incubation for two hours at $25^{\circ} \mathrm{C}$ the plates were again washed in PBS-TWEEN, and $100 \mu \mathrm{l}$ of $50 \mathrm{ng} / \mathrm{ml}$ biotinylated antihuman IgG (Vector Laboratories, BA3080) or biotinylated antihuman IgA (Vector Laboratories, BA3030) was added to each well and incubated for a further two hours at $25^{\circ} \mathrm{C}$. The plates were again washed three times with PBS-TWEEN, and each well was incubated with avidin-horseradish peroxidase complex for 30 minutes at $25^{\circ} \mathrm{C}$ (Vectastain Elite $A B C$, Vector Laboratories). Unbound reagent was washed off with PBS-TWEEN, and the enzyme was detected by the addition of $50 \mu \mathrm{l} 4 \mathrm{mg} / \mathrm{ml} o$-phenylenediamine dihydrochloride as described.

Each sample and standard was performed in triplicate, and mean results were expressed as OD495 nm units with positive controls being shown for 1:2000 dilution of anticytokeratin antibody and 1:5000 dilution of antitropomyosin antibody.

rounds of isoelectric precipitation at $\mathrm{pH} 4.6$ in the presence of $1 \mathrm{M} \mathrm{KCl}$ followed by $\left(\mathrm{NH}_{4}\right)_{2} \mathrm{SO}_{4}$ fractionation between $53 \%$ and $60 \%$ saturation as previously described. ${ }^{20}$ Throughout these purification procedures the protein concentration was adjusted to 1 $\mathrm{mg} / \mathrm{ml}$, to minimise coprecipitation of the troponin complex. Finally tropomyosin preparations were dialysed against water, freeze dried, and stored at $-20^{\circ} \mathrm{C}$.

CaCo-2 and Lim-1863 epithelial cell lines CaCo-2 and Lim-1863 cells were grown as previously described 2122 respectively and maintained at $37^{\circ} \mathrm{C}$ in $5 \% \mathrm{CO}_{2} / 95 \%$ air, being fed weekly with the appropriate medium in a class II laminar flow hood.

\section{ELISA quantification of antiepithelial cell and antitropomyosin immunoglobins}

To quantify antiepithelial cell and antitropomyosin immunoglobulins microtitre plates (96 wells, Maxisorb, Nunc) were coated with $100 \mu \mathrm{l}$ of a preparation of $\mathrm{CaCo}-2$ or $\mathrm{Lim}$ 1863 cell membranes prepared as described previously ${ }^{19}$ at a protein concentration of 1 $\mathrm{mg} / \mathrm{ml}$ or with tropomyosin at a concentration of $3 \mathrm{mg} / \mathrm{ml}$ in freshly prepared carbonate buffer pH $9 \cdot 6^{23}$ by incubation at $4^{\circ} \mathrm{C}$ overnight. The plates were each washed three times with PBS containing $0.05 \%(\mathrm{v} / \mathrm{v})$ TWEEN 20 before blocking with $5 \%(\mathrm{w} / \mathrm{v})$ bovine serum albumin and $1 \%$ goat serum in PBS for one hour at $37^{\circ} \mathrm{C}$ and washed a further three times in PBSTWEEN. Samples of mucosal immunoglobulins and serum from each patient were serially diluted in PBS-TWEEN and $100 \mu \mathrm{g}$ each was loaded in triplicate to the plates. Blanks consisted of protein coated wells that had no serum or mucosal immunoglobulins added. A set of standards were made for every plate by serial dilutions of a monoclonal antipancytokeratin antiserum (for cell line experiments; C2562, Sigma) or antitropomyosin $\mathrm{mAb}$ (for tropomyosin experiments;

\section{Protein assay}

Proteins were assayed using the bicinchoninic acid method (Pierce). ${ }^{24}$

\section{Statistical methods} data from different patient groups using the Wilcoxon signed rank test for unpaired samples using the SPSS package on the Digital Equipment Corporation VAX cluster (VAX 8800 ) of the computing service of the University of London. ${ }^{25}$ The molecular weight of unknown proteins was calculated using Microsoft Excel from a least squares fit of $\log _{10}$ standard molecular weights and migration distance.

\section{Results}

Antiepithelial and antimucosal immunoglobulins in patients with UC

Mucosal immunoglobulins from patients with UC, Crohn's disease, and controls were extracted from endoscopic washings of the colonic mucosa. Quantification of these samples showed that while IgA is the predominant immunoglobulin in controls, there are high concentrations of IgG detected in patients with active UC or Crohn's disease (Fig 2). Western blots of the washings confirmed that the mucosal immunoglobulins obtained were not degraded by proteolysis (not shown).

To examine serum or mucosal immunoglobulins from patients with UC for the presence of antiepithelial cell antibodies, ELISAs were carried out initially using proteins extracted from the differentiated colonic cell lines Lim-1863 or $\mathrm{CaCo}-2$ (not shown) as target antigens. Specific antibody binding to the extracted $\mathrm{Lim}$ or $\mathrm{CaCo}-2$ proteins was not seen from either serum samples or mucosal wash samples of patients with UC, or serum samples of UC patients with coexistent primary sclerosing cholangitis.
Statistical analysis was performed on ELISA 


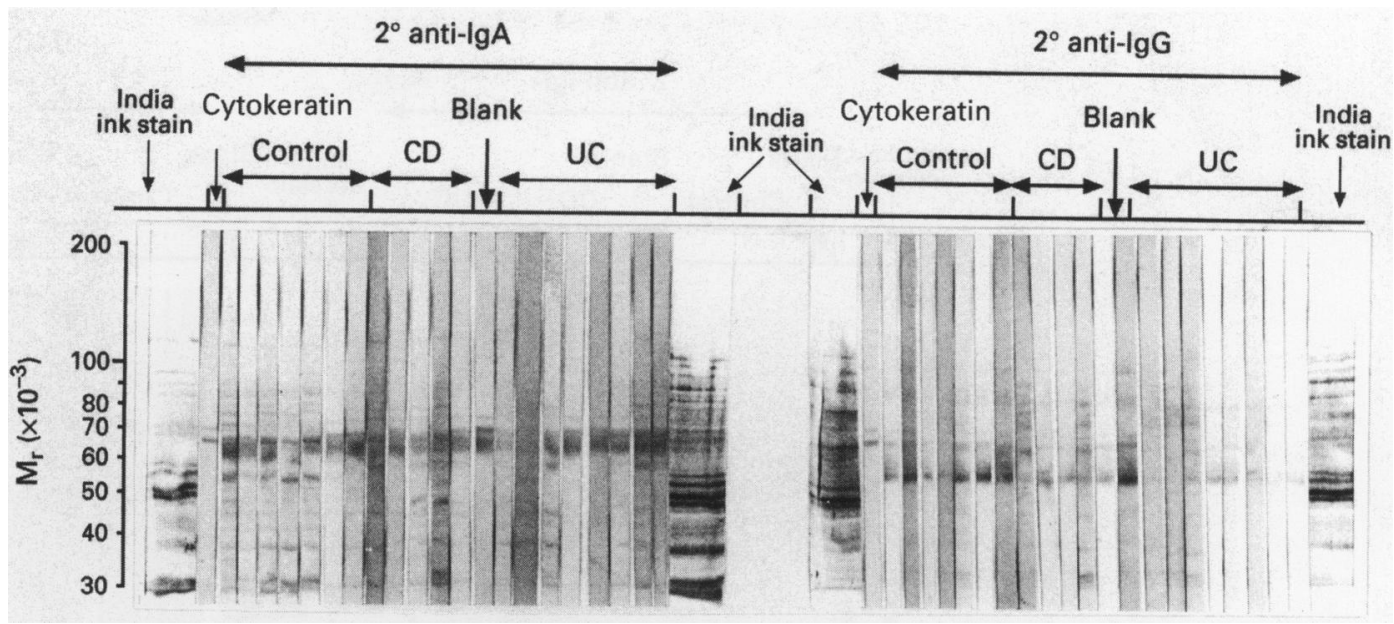

Figure 3: Binding of IgA and IgG from mucosal immunoglobulins derived from colonic washings to normal colonic biopsy proteins. Western blot of colonic proteins processed as shown in Fig 1, with each strip representing binding of a different patient mucosal immunoglobulin sample. Endogenous IgA and IgG in the normal colon was seen in all strips (shown in 'blank' controls where no mucosal immunoglobulin sample was added). A summary of colonic proteins bound by mucosal immunoglobulins in this and parallel experiments for a total of 21 controls, 20 UC, and 17 Crohn's disease is shown in Table I (IgA) or Table II (IgG). There was no protein specifically bound by UC mucosal immunoglobulin samples that was absent in other patient groups.

In these experiments antisera to the cytoskeletal protein cytokeratin and serum from 12 patients with antimitochondrial antibody positive primary biliary cirrhosis were used as positive controls.

Although the Lim-1863 cell line differentiates into crypt like structures in vitro, it remains possible that the above experiments were negative because the cell lines do not express the relevant epithelial antigens of untransformed colonocytes. If colonocytes are directly separated from the underlying mucosa, however, it has been claimed that the surface extrinsic proteins may be lost leading to negative results, ${ }^{14}$ alternatively mucosal homogenates may contain endogenous immunoglobulin, which interferes with the ELISA detection systems. To overcome this, we separated mucosal biopsy homogenates from control subjects, and transferred these proteins to nitrocellulose by western blotting these were then probed with mucosal or serum antibodies.

Results showed that in each case the endogenous IgA ( $\alpha$ heavy chain $M_{r} 55000$ ) or IgG ( $\gamma$ heavy chain $M_{r} 50000$ ) was detected by the secondary antibody (anti-human IgA or IgG respectively) in the experiment (Figs 3-5); the positions of these endogenous bands were confirmed by blank strips in which no serum or mucosal specimens were added at the stage of primary antibody incubation. Additional bands resulting from specific immunoglobulin binding from the patient serum or mucosal wash antibodies (but absent from the blank strips) were seen as detailed later. The detection system in these experiments was shown to be sensitive to antibody concentrations of $\geqslant 20 \mathrm{ng} / \mathrm{ml}$.

Mucosal wash IgA binding to normal colonic mucosal proteins - in mucosal immunoglobulin samples from control subjects there were 14 additional IgA bands from binding to mucosal proteins corresponding to $M_{r} 109000,85000$, $82000,78000,76000,59000,55000$, $52000,48000,46000,43000,38000$, 29000,28000 (Fig 3). In patients with UC and Crohn's disease there were fewer IgA bands present in a lower proportion of patients (Table I) corresponding to proteins of $\mathrm{M}_{\mathrm{r}}$ $85000,76000,52000,46000,43000$, $38000,29000,28000$. As the blot was obtained from mucosal proteins run en bloc and sectioned into strips with both edges being stained from protein to ensure uniform transfer, these differences are not accounted for by inconsistencies in blotting efficiency. Table I

TABLE I Colonic mucosal proteins bound by mucosal and serum IgA

\begin{tabular}{|c|c|c|c|c|c|c|c|c|}
\hline \multirow{2}{*}{$\begin{array}{l}\text { Mucosal } \\
\text { Protein } \\
\left(M_{\mathrm{r}}\right)\end{array}$} & \multicolumn{2}{|l|}{ Control } & \multicolumn{2}{|c|}{ Crohn's disease } & \multicolumn{2}{|c|}{ Ulcerative colitis } & \multicolumn{2}{|c|}{$\begin{array}{l}\text { Ulcerative colitis/ } \\
\text { sclerosing cholangitis }\end{array}$} \\
\hline & $\begin{array}{l}\text { Mucosal } \\
\operatorname{IgA}(\%)\end{array}$ & $\begin{array}{l}\text { Serum IgA } \\
\text { (\%) }\end{array}$ & $\begin{array}{l}\text { Mucosal } \\
\operatorname{Ig} A(\%)\end{array}$ & $\begin{array}{l}\text { Serum IgA } \\
\text { (\%) }\end{array}$ & $\begin{array}{l}\text { Mucosal } \\
\operatorname{Ig} A(\%)\end{array}$ & $\begin{array}{l}\text { Serum } \operatorname{Ig} A \\
\text { (\%) }\end{array}$ & $\begin{array}{l}\text { Mucosal } \\
\lg A\end{array}$ & $\begin{array}{l}\text { Serum } \\
\text { IgA }\end{array}$ \\
\hline 109000 & $16 / 21(76)$ & $4 / 21(14)$ & $0 / 17$ & $0 / 17$ & $0 / 20$ & $0 / 20$ & - & $0 / 12$ \\
\hline 85000 & $18 / 21(85)$ & $0 / 21$ & $0 / 17$ & $0 / 17$ & $0 / 20$ & $0 / 20$ & - & $0 / 12$ \\
\hline 82000 & $15 / 21(71)$ & $0 / 21$ & $2 / 17$ (3) & $0 / 17$ & $4 / 20(20)$ & $0 / 20$ & - & $0 / 12$ \\
\hline 78000 & $16 / 21(76)$ & $0 / 21$ & $0 / 17$ & $0 / 17$ & $0 / 20$ & $0 / 20$ & _- & $0 / 12$ \\
\hline 76000 & $17 / 21(80)$ & $0 / 21$ & $4 / 17$ (4) & $2 / 17$ (11) & $5 / 20(25)$ & $0 / 20$ & - & $0 / 12$ \\
\hline 59000 & $18 / 21(85)$ & $0 / 21$ & $0 / 17$ & $0 / 17$ & $0 / 20$ & $0 / 20$ & _- & $0 / 12$ \\
\hline 55000 & $17 / 21(80)$ & $0 / 21$ & $0 / 17$ & $0 / 17$ & $0 / 20$ & $0 / 20$ & - & $0 / 12$ \\
\hline 52000 & $17 / 21(80)$ & $0 / 21$ & $3 / 17(18)$ & $0 / 17$ & $6 / 20(30)$ & $0 / 20$ & - & $0 / 12$ \\
\hline 48000 & $15 / 21(71)$ & $0 / 21$ & $0 / 17$ & $0 / 17$ & $0 / 20$ & $0 / 20$ & - & $0 / 12$ \\
\hline 46000 & $17 / 21(80)$ & $0 / 21$ & $5 / 17(29)$ & $0 / 17$ & $7 / 20$ (35) & $0 / 20$ & - & $0 / 12$ \\
\hline 43000 & $16 / 21(76)$ & $3 / 21(14)$ & $4 / 17$ (4) & $0 / 17$ & $6 / 20(30)$ & $0 / 20$ & - & $0 / 12$ \\
\hline 38000 & $21 / 21(100)$ & $3 / 21$ (14) & $12 / 17(70)$ & $3 / 17$ (17) & $16 / 20(80)$ & $0 / 20$ & - & $0 / 12$ \\
\hline 29000 & $19 / 21(90)$ & $0 / 21$ & $4 / 17(23)$ & $0 / 17$ & $2 / 20(10)$ & $0 / 20$ & - & $0 / 12$ \\
\hline 28000 & $19 / 21(90)$ & $3 / 21(14)$ & $10 / 17(59)$ & $0 / 17$ & $8 / 20(40)$ & $0 / 20$ & - & $0 / 12$ \\
\hline
\end{tabular}




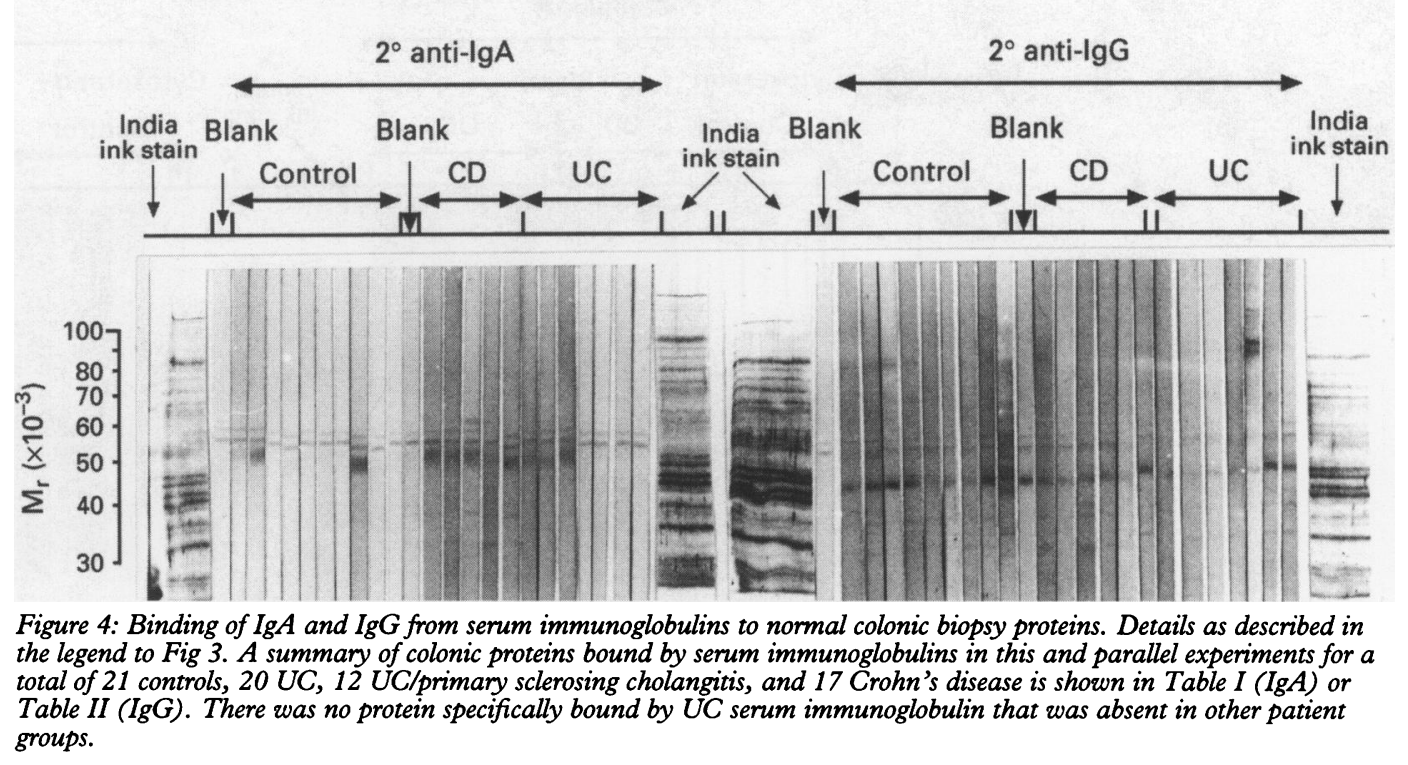

summarises the presence or absence of each band for the different patient groups.

Serum Ig $A$ binding to normal colonic mucosal proteins - compared with mucosal immunoglobulin preparations, there was very little serum IgA binding to colonic mucosal proteins. Weak bands on the western blots in a small proportion of controls and Crohn's disease cases were seen at $M_{r} 109000,85000$, $76000,43000,38000$, and 28000 (Fig 4). No serum IgA binding to mucosal proteins from UC or primary sclerosing cholangitis/UC cases was seen (Table I).

Mucosal wash IgG binding to normal colonic mucosal proteins - some faint protein bands were also detected through mucosal IgG binding to normal colonic mucosal proteins in the western blot (Fig 3). These proteins corresponded to $M_{r} 93000,83000,76000$, $45000,38000,31000,28000$, and 29600 . None of these were exclusively seen in either UC or Crohn's disease; Table II summarises the presence or absence of each band for the patient groups.

Serum IgG binding to normal colonic mucosal proteins - some bands were also weakly seen from serum IgG binding to normal colonic mucosal proteins of $M_{\mathrm{r}} 162000,126000$, $122000,93000,83000,66000,45000$, $38000,31000,29000,28000$ (Figs 4 and 5),

but no proteins were specifically bound by UC serum but not in Crohn's disease or controls (Table II).

In positive control serum samples of patients with primary biliary cirrhosis protein clear bands of 70000 or 45000 were seen consistent with the known molecular weight of the mitochondrial M2 complex ( ${ }^{26}$, Fig 5).

The 38000 molecular weight band was weakly seen in 12 of 20 patients with UC, 11 of 17 Crohn's disease patients, and 15 of 21 controls, and precisely aligned with tropomyosin detected on a separate strip with monoclonal antitropomyosin antibody.

\section{Antitropomyosin antibodies in serum and mucosal immunoglobulins}

In view of the report that the 40000 antigen is an isoform of human intestinal tropomyosin, ${ }^{12}$ we isolated this protein from the normal human colonic mucosa and purified it to two bands of 37000 and 39000 on a polyacrylamind gel corresponding to the two subunits previously described ${ }^{20}$ that comigrated with commercially purified porcine tropomyosin and reacted on western blotting as a single band with antichicken tropomyosin monoclonal (Fig 6). The purified human protein was then used as antigen in ELISA experiments.

TABLE II Colonic mucosal proteins bound by mucosal and serum IgG

\begin{tabular}{|c|c|c|c|c|c|c|c|c|}
\hline \multirow{2}{*}{$\begin{array}{l}\text { Mucosal } \\
\text { Protein } \\
\left(M_{\mathrm{r}}\right)\end{array}$} & \multicolumn{2}{|l|}{ Control } & \multicolumn{2}{|c|}{ Crohn's disease } & \multicolumn{2}{|c|}{ Ulcerative colitis } & \multicolumn{2}{|c|}{$\begin{array}{l}\text { Ulcerative colitis/ } \\
\text { sclerosing cholangitis }\end{array}$} \\
\hline & $\begin{array}{l}\text { Mucosal } \\
\operatorname{IgG}(\%)\end{array}$ & $\begin{array}{l}\text { Serum IgG } \\
(\%)\end{array}$ & $\begin{array}{l}\text { Mucosal } \\
\operatorname{IgG}(\%)\end{array}$ & $\begin{array}{l}\text { SerumIgG } \\
(\%)\end{array}$ & $\begin{array}{l}\text { Mucosal } \\
\operatorname{IgG}(\%)\end{array}$ & $\begin{array}{l}\text { Serum IgG } \\
(\%)\end{array}$ & $\begin{array}{l}\text { Mucosal } \\
\text { IgG }\end{array}$ & $\begin{array}{l}\text { Serum IgG } \\
(\%)\end{array}$ \\
\hline $\begin{array}{r}162000 \\
126000 \\
122000 \\
93000 \\
83000 \\
76000 \\
66000 \\
45000 \\
38000 \\
31000 \\
29000 \\
28000\end{array}$ & $\begin{array}{l}0 / 21 \\
0 / 21 \\
7 / 21(33) \\
6 / 21(29) \\
8 / 21(38) \\
3 / 21(14) \\
0 / 21 \\
3 / 21(14) \\
5 / 21(24) \\
0 / 21 \\
2 / 21(9) \\
2 / 21(9)\end{array}$ & $\begin{array}{r}8 / 21(38) \\
13 / 21(62) \\
12 / 21(57) \\
8 / 21(38) \\
7 / 21(33) \\
0 / 21 \\
5 / 21(24) \\
4 / 21(19) \\
15 / 21(71) \\
0 / 21 \\
0 / 21 \\
0 / 21\end{array}$ & $\begin{array}{l}0 / 17 \\
0 / 17 \\
0 / 17 \\
8 / 17(47) \\
9 / 17(53) \\
6 / 17(35) \\
0 / 17 \\
6 / 17(35) \\
4 / 17(23) \\
0 / 17 \\
5 / 17(29) \\
5 / 17(29)\end{array}$ & $\begin{array}{r}3 / 17(17) \\
9 / 17(53) \\
10 / 17(59) \\
3 / 17(18) \\
2 / 17(12) \\
0 / 17 \\
0 / 17 \\
2 / 17(12) \\
11 / 17(65) \\
5 / 17(29) \\
6 / 17(35) \\
7 / 17(41)\end{array}$ & $\begin{array}{l}0 / 20 \\
0 / 20 \\
0 / 20 \\
6 / 20(30) \\
4 / 20(20) \\
6 / 20(30) \\
0 / 20 \\
9 / 20(45) \\
6 / 20(30) \\
4 / 20(20) \\
4 / 20(20) \\
7 / 20(35)\end{array}$ & $\begin{array}{l}2 / 20(10) \\
4 / 20(20) \\
5 / 20(25) \\
0 / 20 \\
0 / 20 \\
0 / 20 \\
2 / 20(10) \\
2 / 20(10) \\
12 / 20(60) \\
3 / 20(15) \\
5 / 20(25) \\
6 / 20(30)\end{array}$ & $\begin{array}{l}- \\
- \\
- \\
- \\
- \\
- \\
- \\
- \\
- \\
- \\
- \\
-\end{array}$ & $\begin{array}{l}0 / 12 \\
3 / 12(25) \\
6 / 12(50) \\
0 / 12 \\
0 / 12 \\
4 / 12(33) \\
5 / 12(42) \\
3 / 12(25) \\
7 / 12(58) \\
5 / 12(42) \\
6 / 12(50) \\
6 / 12(50)\end{array}$ \\
\hline
\end{tabular}


These showed no evidence for significantly increased anti-testinal tropomyosin titres in the serum (Fig 7) or mucosal antibody preparations (not shown) from patients with UC

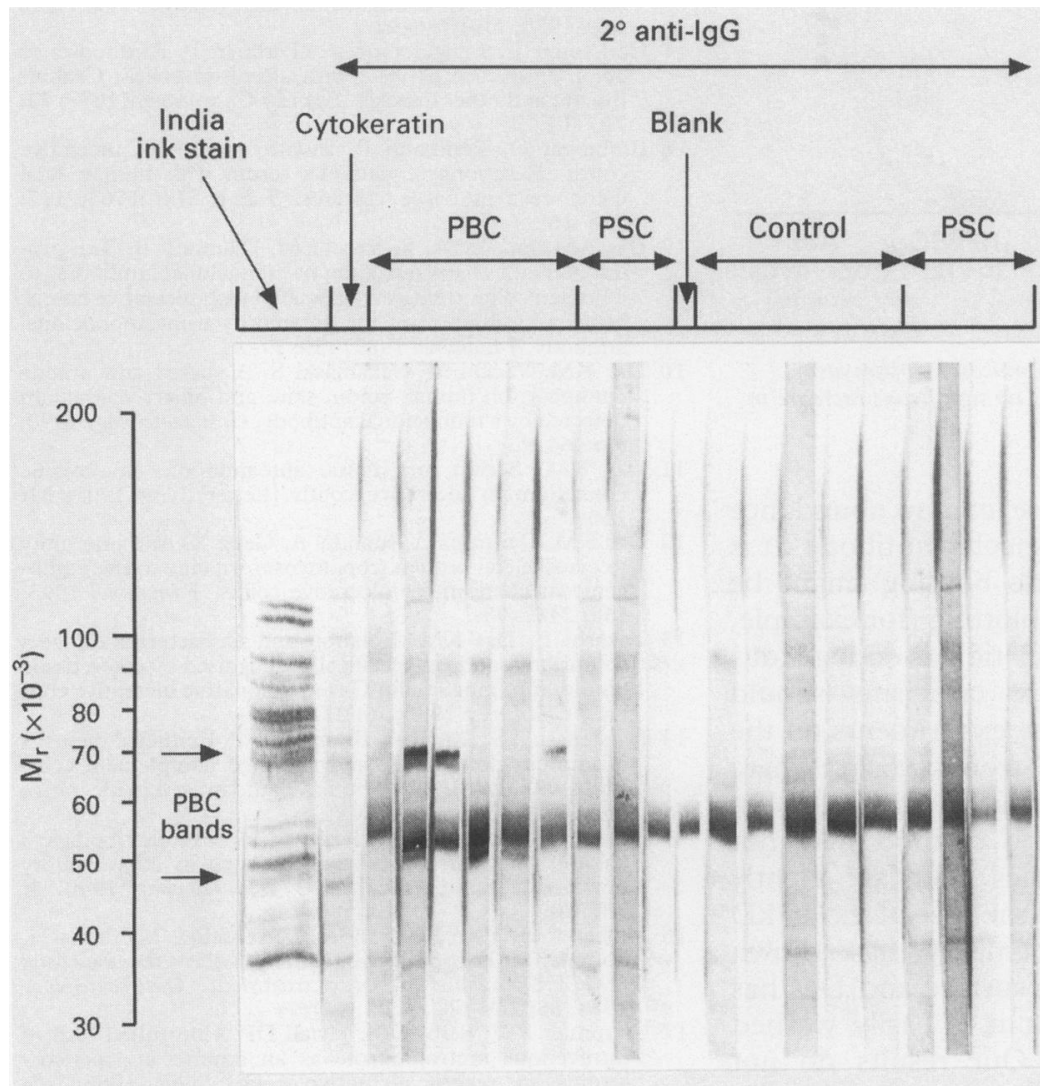

Figure 5: Binding of IgG from serum of patients with primary biliary cirrhosis and UC/primary sclerosing cholangitis to normal colonic biopsy proteins. Details as described in the legend to Fig 3. A summary of colonic proteins specifically bound by serum IgG in a total of 12 UC/primary sclerosing cholangitis patients is shown in Table II. There was no protein specifically bound by UC/primary sclerosing cholangitis serum that was absent in other patient groups. The positions of mitochondrial proteins bound by primary biliary cirrhosis serum are marked (IgG binding was seen in 11 of 12 patients, the remaining patient had an IgA antimitochondrial antibody).

A

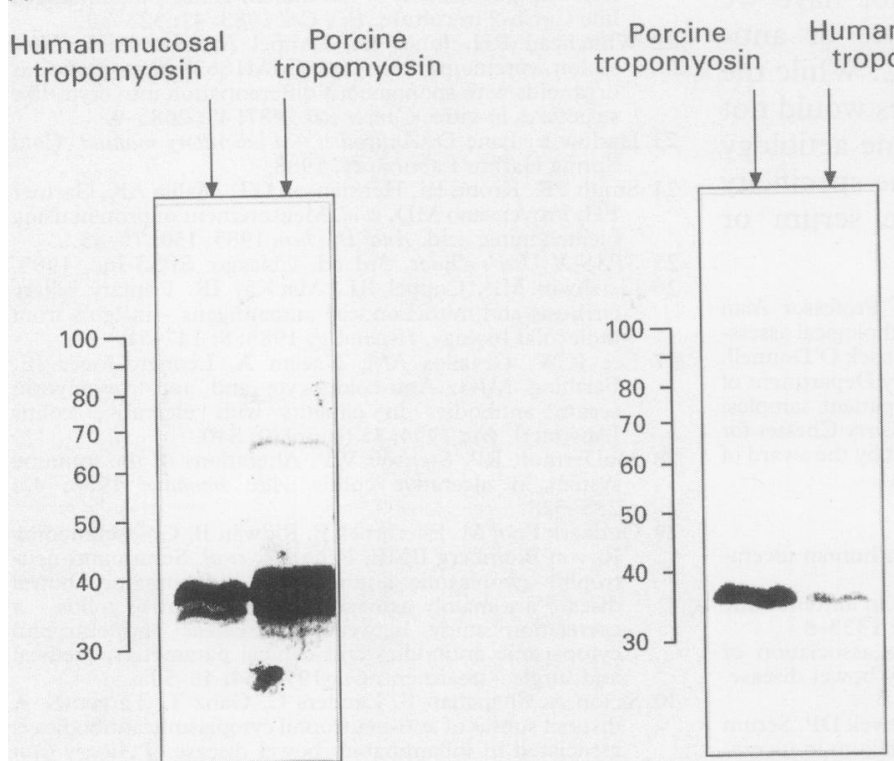

Figure 6: (A) Purified human mucosal tropomyosin separated by $12 \cdot 5 \%$ SDS polyacrylamide gel electrophoresis and stained with Coomassie blue. The two subunits of tropomyosin of 37000 and 39000 comigrated with those of porcine tropomyosin; $(B)$ western blot of purified human mucosal tropomyosin using monoclonal antichicken tropomyosin antibody. A single band of 39000 was seen. $(n=21)$, coexistent UC colitis, and primary sclerosing cholangitis $(n=12)$ or Crohn's disease $(n=17)$ compared with controls with irritable bowel syndrome $(n=21)$ or noninflammatory bowel disease colonic inflammation $(n=8)$. We and others ${ }^{27}$ have also been unable to detect increased mucosal or serum titres to porcine tropomyosin in UC patients compared with controls.

\section{Discussion}

We have not found any evidence that there is specific binding of serum or mucosal antibodies from patients with UC to normal mucosal proteins, nor have we been able to see specific binding to differentiated $\mathrm{Lim}$ or CaCo-2 colonic epithelial cell lines.

It is difficult to equate the claim that significantly increased antitropomyosin serum titres can be detected in most UC patients with the negative results in these experiments obtained with our purified human colon tropomyosin preparation despite following the previously reported ELISA technique. ${ }^{12}$ As it has been suggested that cross reaction between the colonic and biliary isoforms of tropomyosin may account for primary sclerosing cholangitis as an extraintestinal complication of $\mathrm{UC}^{10}$ we included serum from this patient group, but again compared with controls there were no significantly increased titres. We have also shown that there is sometimes a weak band on western blotting at $M_{r} 38000$ from binding of serum IgG corresponding to the position of colonic tropomyosin identified using a monoclonal antibody; however, this band is present with similar frequencies in Crohn's disease $(65 \%)$ and UC $(60 \%)$ and is also seen in control patients $(71 \%)$.

Our western blot experiments have shown IgG directed against other proteins isolated from normal colonic mucosal biopsy specimens, but none of these were specific for UC, and it is well known that antimucin, antilymphocyte and other antibodies directed against the colonic mucosa are produced in inflammatory bowel disease. ${ }^{28}$ The bands at $122000,126000,162000$ are consistent with previously reported antimucin antibodies. ${ }^{6}$ As autoantibodies to normal colonic mucosal proteins were being sought in these experiments, we used control biopsy specimens to prepare target antigens for western blots in which there would be a low neutrophil content; it follows that antineutrophil antibodies would not be seen with this experimental design. ${ }^{29} 30$ The IgA bands seen in mucosal immunoglobulin preparations of control subjects and with lower frequency in inflammatory bowel disease patients are at the same molecular weight as proteins detected in western blots of commensal enterobacteria (Khoo and Macpherson, submitted data), and thus result from the presence of enterobacterial proteins in the mucosal preparations.

Of course it remains possible that our detection methods on western blotting may be insufficiently sensitive to detect either specific mucosal or serum antibodies, which are 


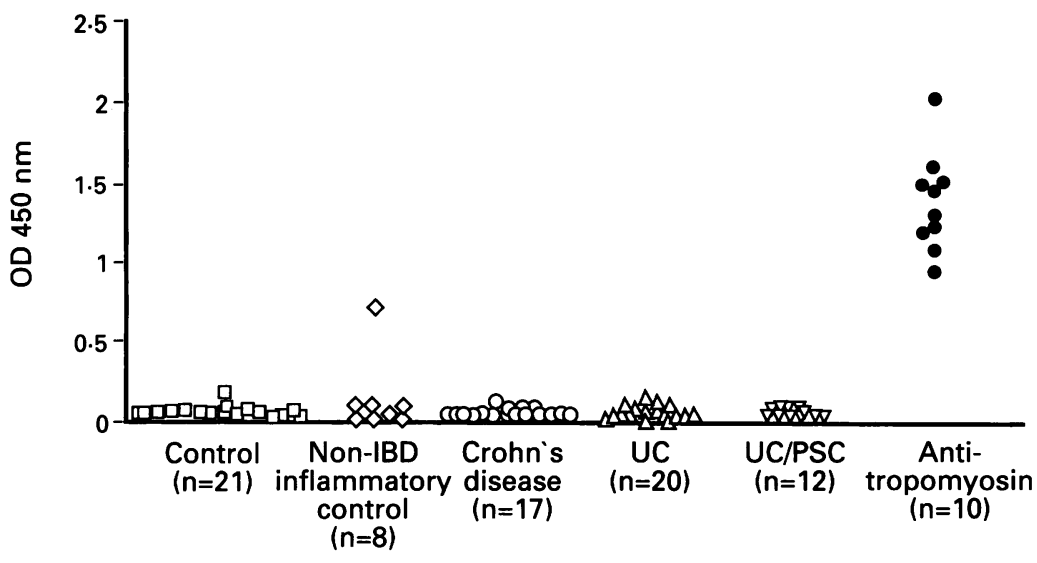

Figure 7: ELISA of immunoglobulin binding to purified human mucosal tropomyosin. Positive controls shown for antitropomyosin antibody. There was no significant increase in binding in the UC or UC/primary sclerosing cholangitis groups.

important in UC because of low abundance proteins or low titres of specific antibody. It is also possible that specific binding might be obscured on the western blotting (for example, by running at the same position as endogenous immunoglobulins). These criticisms should not apply, however, to the experiments on the $40 \mathrm{kD}$ human intestinal tropomyosin, where purified antigen is available for ELISAs. Furthermore, the washing method may not isolate mucosal antibodies that are tightly tissue bound (although in the case of the $40 \mathrm{kD}$ antigen, immunohistochemistry has shown that it is on the lumunal surface and Das has previously suggested that it is easily washed off the colonocytes, ${ }^{14}$ ). Our results do not support the hypothesis ${ }^{19}$ that immunoglobulin localised on the apical epithelial surface in patients with active UC is directed against tropomyosin, however the identity of the antigen(s) and whether these are colonocyte or luminal proteins, remains unclear.

In summary our data have not confirmed the suggestion that the serum of most UC patients contain high antibody titres to the ' $40 \mathrm{kD}$ ' tropomyosin (colonic isoform), nor have we been able to detect anticolonocyte or antimucosal antibodies specific for UC. While the finding of anticolonocyte antibodies would not necessarily establish an autoimmune aetiology for UC, our data cast doubt on the specificity of such antibodies either in the serum or mucosa of UC patients.

We are grateful for the help and support of Professor Alan McGregor and Dr Ian Forgacs, and for histopathological assessments carried out by Drs Alison Marker and Patrick O'Donnell. Sister S Ridyard and the staff of the Day Surgery Department of King's College Hospital helped in collecting patient samples. We are grateful to Dr R Whitehead and to Dr Kerry Chester for We are grateful to Dr R Whitehead and to Dr Kerry Chester for
the Lim-1863 cell line. This work was supported by the award of an MRC Clinician Scientist Fellowship to AJSM.

1 Broberger O, Perlman P. Autoantibodies in human ulcerative colitis. $\mathcal{F}$ Exp Med 1959; 110: 657-74.

2 Raedler A, Schreiber S. Is ulcerative colitis an autoimmune disease. Dtsch Med Wochenschr 1992; 117: 1333-8.

3 Snook JA, De Silva HJ, Jewell DP. The association of autoimmune disorders with inflammatory bowel disease. Qf Med 1989; 72: 835-40.

4 Snook JA, Lowes JR, Wu KC, Priddle JD, Jewell DP. Serum and tissue autoantibodies to colonic epithelium in ulcerative colitis. Gut 1991; 32: 163-6.
5 Hibi TOM, Kobayashi K, Brown WR, Toda K, Takaishi $\mathrm{H}$, Hosoda $\mathrm{Y}$, et al. Enzyme linked immunosorbent assay (ELISA and immunoprecipitation studies on anti-goblet cell antibody using a mucin producing cell line in patients with inflammatory bowel disease. Gut 1994; 35: 224-30.

6 Fiocchi C, Roche JK, Wichener WN. High prevalence of antibodies to intestinal epithelial cells in patients with inflammatory bowel disease and their relatives. Ann Intern Med 1989; 110: 786-94.

7 Carlsson HE, Langercrantz R, Perlman P. Antibodies to colon antigen in patients with ulcerative colitis, Crohn's
disease and other diseases. Scand $f$ Gastroenterol 1977; 12: disease and

8 Broberger $O$, Perlmann $P$. In-vitro studies of ulcerative colitis. Reactions of patient's serum with human fetal colon cells in tissue cultures. F Exp Med 1963; 117: 705-16.

9 Das KM, Sakamaski S, Vecchi M, Diamond B. The production and characterisation of monoclonal antibodies to a human colonic antigen associated with ulcerative colitis: cellular localisation of the antigen by using monoclonal antibody. F Immunol 1987; 139: 77-84.

10 Das KM, Vecchi M, Sakamaski S. A shared and unique epitope(s) on human colon, skin, and biliary epithelium epitope(s) on human colon, skin, and biliary epithelium 98: 464-9.

11 Das KM. Serum and tissue antoantibodies to colonic epithelium in ulcerative colitis [Letter]. Gut 1991; 32:

12 Das KM, Dasgupta A, Mandal A, Geng X. Autoimmunity to cytoskeletal protein tropomyosin - a clue to the pathogenic mechanism for ulcerative colitis. F Immunol 1993; 150: 2487-93.

13 Takashi F, Das KM. Isolation and characterisation of a colonic autoantigen specifically recognised by colon tissue bound immunoglobulin $\mathrm{G}$ from idiopathic ulcerative colitis. 7 Clin Invest 1985; 76: 311-8.

14 Halstensen TS, Das KM, Brandtzaeg P. Epithelial deposits of immunoglobulin G1 and activated complement colocalise with the Mr $40 \mathrm{kd}$ putative autoantigen in ulcerative colitis. Gut 1993; 34: 650-7.

15 Cantrell M, Prindiville T, Gershwin ME. Autoantibodies to colonic cells and subcellular fractions in inflammatory bowel disease: do they exist? $\mathcal{F}$ Autoimmun 1990; 3: 307-20.

16 Malchow H, Ewe K, Brandes JW, Goebell H, Ehms H, Sommer H. European cooperative Crohn's disease study (ECCDS): results of drug treatment. Gastroenterology 1984; 86: 249-66.

17 Chapman RW, Selby WS, Jewell DP. Controlled trial of intravenous metronidazole as an adjunct to corticosteroids in severe ulcerative colitis. Gut 1986; 27: 1210-2.

18 Macpherson AJS, Jones-Mortimer MC, Henderson PJF. Identification of the AraE transport protein of Escherichia Identification of the AraE transport

19 Peters TJ. Analytical subcellular fractionation of jejunal biopsy specimens: methodology and characterisation of the organelles in normal tissue. Clin Sci Mol Med 1976; 51: 557-74.

20 Cummins P, Perry SV. The subunits and biological activity of polymorphic forms of tropomyosin. Biochem $\mathcal{F} 1973$; 133: 765-77.

21 Pinto $M$, Robine-Leon S, Appay M-D, Kedinger M, Triadou N, Dussaulx E, et al. Enterocyte-like differentiation and polarisation of the human colon carcinoma cell tion and polarisation of the human colon carcinom

22 Whitehead RH, Jones JK, Gabriel A, Lukies RE. New Colon carcinoma cell line (LIM1863) that grows as organoids with spontaneous differentiation into crypt-like structures in-vitro. Cancer Res 1987; 47: 2683-9.

23 Harlow E, Lane D. Antibodies - a laboratory manual. Cold Spring Harbor Laboratory, 1988

24 Smith PK, Krohn RI, Hermanson GT, Mallia AK, Gartner $\mathrm{FH}$, Provenzano MD, et al. Measurement of protein using bicinchoninic acid. Anal Biochem 1985; 150: 76-85.

25 SPSS-X User's Guide. 3rd ed. Chicago: SPSS-Inc, 1983.

26 Gershwin ME, Coppel RL, MacKay IR. Primary biliary cirrhosis and mitochondrial autoantigens - insights from molecular biology. Hepatology 1988; 8: 147-51.

27 Lee JCW, Cevallos AM, Naeem A, Lennard-Jones JE, Farthing MJG. Anti-colonocyte and anti-tropomyosin Farthing MJG. Anti-colonocyte and anti-tropomyosin serum antibodies in patients with ulce

28 McDermott RP, Stenson WF. Alterations of the immune system in ulcerative colitis. Adv Immunol 1988; 42: 285-328.

29 Oudkerk Pool M, Ellerbroek P, Ridwan B, Goldschmeding $R$, von Blomberg BME, Peña AS, et al. Serum anti-neurophil cytoplasmic antibodies in inflammatory bowel disease are mainly association with ulcerative colitis - a correlation study between perinuclear antineutrophil cytoplasmic antibodies and clinical parameters, medical and surgical treatment. Gut 1993; 34: 46-50.

30 Saxon A, Shanahan F, Landers C, Ganz T, Targan S. A distinct subset of anti-neutrophil cytoplasmic antibodies is associated in inflammatory bowel disease. $\boldsymbol{F}$ Allergy Clin Immunol 1990; 86: 202-10. 